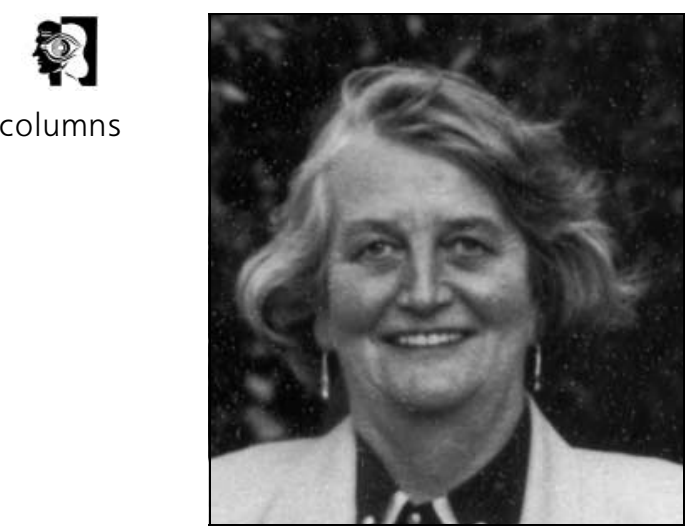

\section{Doreen Louisa Patricia Marshall}

\section{Formerly Consultant Psychiatrist Morpeth}

Dr Tricia Marshall, who died on 27 October 2002 from lung cancer, was born in Carlisle on November 9 1929. After qualifying MB, BS(Dur.) in 1952, she returned to Carlisle to spend a year as a trainee general practitioner - her intention being to make that her career.

In 1954, she married Merlin Marshall. Over the next 10 years, she had a very busy life, working part-time in general practice while raising her five children. As if this was not enough, she looked after her aunt who had Parkinson's disease and then her mother-in-law who had senile dementia for 11 years.

In the sixties, she became involved with The Catholic Marriage Advisory Council (CMAC) and for over 20 years did voluntary work in marital and psychosexual counselling. For 6 years, she was a member of the National Executive Council CMAC with one year as Chairman. She travelled widely abroad, lecturing on counselling and psychosexual matters. From 1979 to 1983 , she was a member of the Home Office/Department of Health and Social Security Working Party on Marriage Guidance, which published a consultative Document 'Marriage Matters'.

This experience led her into psychotherapy, in which she maintained a lifetime interest. In 1983, she gained a Diploma in Psychotherapy at Leeds. After 2 years as a registrar in psychotherapy, she moved into general psychiatric training and in 1978, she became MRCPsych and was later elected Fellow.

1986 saw her appointed Consultant Psychiatrist at St George's Hospital Morpeth, where she worked until retirement in April 2000 at the age of 70. In addition to her psychiatric work there, she took an active part in administration, being a member of the Medical Executive Committee for several years and chairman for some time.
She was loved, and to some extent feared, by staff and patients - feared because of her considerable presence and a way she had of quelling dissenters (from the chairman of the Executive Committee downwards) with 'one of her looks'. On the other hand, she was nonjudgemental. Their affection was demonstrated by the unusually large number of staff and patients who attended her funeral.

After retirement, she did voluntary work for the National Trust, the local hospice, Age Concern, and produced news tapes for the hearing-impaired.

Tricia came from a large extended family where hospitality was the name of the game. She carried on this tradition in her home in Newcastle. The many friends of her children and others were always welcome to stay.

Tricia is survived by three sons, two daughters and eleven grandchildren. They all, with her many friends, miss her sadly.

\section{Anne Glavina}

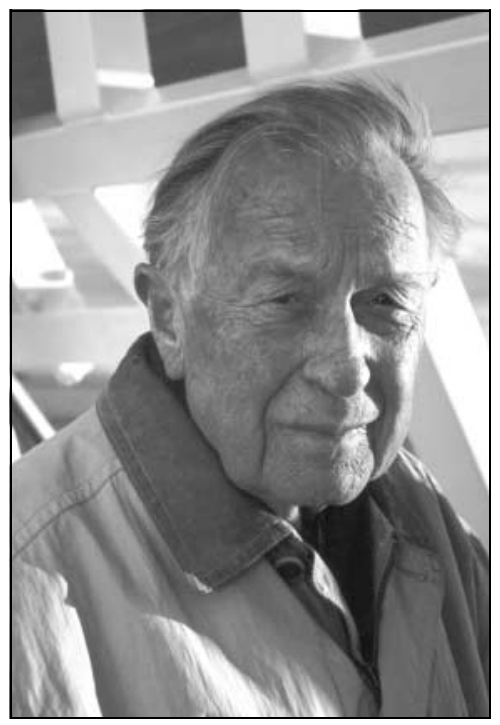

\section{Professor Gerdt Erik Wretmark}

\section{Formerly Corresponding} Fellow of the Royal College of Psychiatrists

Gerdt Wretmark was prototypical of those overseas postgraduates who develop an enduring attachment to their British institute and retain allegiance when they return, magisterially specialised, to their homeland.

Wretmark came from Sweden to the Institute of Psychiatry and assimilated with quiet intensity all that London and
Maudsley Hospital psychiatry had to offer during 1955-56 (when he last spoke and wrote to me, at the end of his life, it was about his writing on the quintessential London painter Hogarth, with focus on his Bedlam scenes). He repeatedly returned to London, for conferences at the Royal College and to meet professional friends, notably his mentor Denis Leigh.

He was born in Malmö on 23 April 1918 (it was important to him that two Williams, Shakespeare and Turner, had the same birthdate). His doctoral thesis on The Peptic Ulcer Individual was presented in Lund in 1953, and he was appointed Assistant Professor the following year. He became head of the Department of Psychiatry at Linköping in 1956, was appointed Professor in 1970 and worked there until he retired in 1983.

The principles he brought from the Maudsley were translated to Swedish professional practice. Humane attitudes were paramount - staff had to discard white clinical coats, and good communication was regarded a core element of all clinical work. As a psychiatrist, he saw himself as duty-bound to instill the same therapeutic attitude, not only in psychiatrists in training, but also in medical students, general practitioners, physiotherapists and occupational therapists. He set up practical demonstrations: his drying-out facility for alcoholics ministering to the affluent as well as the 'down and outs' - was unforgettably dramatic for the benign detachment and thoroughness of the procedure, in which all the local services were marshalled. In 1978, the medical students of Linköping gave him a special award for teaching. He was recognised as a pioneer in medical ethics in Sweden and his widely-used textbook appeared in 1982.

He lived in Uppsala during 1985-89, his remarriage to Astrid Andersson Wretmark lasting 24 years. Together they trained to qualify as ordinands in the Church of Sweden in communication and counselling, and jointly studied perinatal death as a pastoral problem. His youngest daughter Hanna was born in 1981; by former marriages he had four daughters: Ulla, Kerstin, Eva and Maria. From 1989, he worked in private psychiatric practice in Visby for 10 years, and in 2000 published Möten Broar: Berättelser ur minnet (Encounter Bridges: Stories from my memory). He was always culturally aware, and from his youth he collected Chinese art.

He died on 29 December 2001 of liver cancer, probably from the bile duct. He wanted Astrid to conduct the funeral service in Visby Cathedral, but she chose instead to speak during the service, of his capacity for dialogue and his redeeming sense of humour. His ashes are buried in the family grave at Malmö.

Henry Walton 